\title{
Identification of renin in resident alveolar macrophages and monocytes:
}

\section{HPLC and immunohistochemical study}

\author{
BALÁZS DEZSÖ*, ARNE HOJ NIELSEN and KNUD POULSEN \\ Department of Btochemistry, Royal Dental College and the Medical School, 3C Blegdamsvej, Copenhagen 2200 N, Denmark \\ - Present address for correspondence: Department of Pathology, University Medical School, Nagyerdei krt. 98, POB: 24, H-4012 Debrecen, \\ Hungary
}

\section{Summary}

Normal, unstimulated alveolar macrophages (AM) and monocytes (Mo) from both mice and rats have been shown to exhibit an angiotensin-I-forming enzyme. This protease has a similar or identical molecular weight to plasma renin as judged by HPLC analysis. In addition, the enzyme activity could be almost completely inhibited by a specific antibody to pure mouse submaxillary gland renin. This indicates that the angiotensin-I-generating protease in $A M$ and Mo is identical to true renin. These results are in accordance with those of immunocytochemical studies, since the cells sharing immunoreactive renin are macrophages and mono-

cytes. The low percentage of renin positive cells may indicate a functionally different and probably distinct subpopulation of AM and Mo.

The presence of renin and angiotensins and angiotensin-I-converting enzyme in normal macrophages and monocytes seems to be common. Hence, the data presented raise the possibility that an intracellular renin-angiotensin system may infact exist in a certain subpopulation(s) of normal macrophages and monocytes.

Key words: renin, alveolar macrophage, monocyte.

\section{Introduction}

A lot of experimental data point to the possible existence of an extrarenal angiotensin system in different tissues and cells (Fernandez et al. 1986; Fishman et al. 1981; Ganten et al. 1976; Klickstein et al. 1982; Naruse et al. 1985; Okamura et al. 1981; Schelling et al. 1979; Weinstock \& Blum, 1983). However, this angiotensin cascade may differ in its initiator component, i.e. in the first enzyme that is capable of generating angiotensin-I (AI) or angiotensin-II (AII) directly (Tonnesen et al. 1982), from the substrate available. In a former paper we demonstrated that alveolar macrophages and peripheral blood monocytes also contain angiotensins (Dezsö et al. 1988). Although, it is not clear whether these peptides are trapped or generated de novo by mononuclear phagocytes, our results have provided a further assumption that macrophages/monocytes may also contain renin or a renin-like enzyme.

This paper demonstrates the presence of the enzyme renin in alveolar macrophages and monocytes from mice and rats, which is inhibitable by a specific antibody to pure mouse submaxillary gland renin. The renin was detected by radioimmunoassay (RIA), and identified by a high performance liquid chromatography (HPLC) analysis and an immunocytochemical method.

Journal of Cell Science 91, 155-159 (1988)

Printed in Great Britain (C) The Company of Biologists Limited 1988

\section{Materlals and methods}

\section{Cell separation}

Anticoagulated blood from male Balb/C mice and Wistar rats was centrifuged at $200 \mathrm{~g}$ to remove the plasma containing the majority of the platelets. After reconstituting the buffy coat with serum-free medium 199 (Flow Lab.), peripheral blood monocyte (Mo) isolation from Percoll-separated mononuclear cells (Böyum, 1968) from both mice (M-Mo) and rats (R-Mo) was carried out by a $90 \mathrm{~min}$ period of adherence to plastic Petri dishes (Böyum, 1968). Alveolar macrophages (AM) from mice (M-AM) and rats (R-AM) were obtained by bronchopulmonary lavage as described (Alblas \& Furth, 1979). After a $90 \mathrm{~min}$ period of adherence to plastic Petri dishes (Nunclon, Denmark) the non-adherent cells were removed by washing the monolayers with serum-free medium 199 containing penicillin and streptomycin (M199-PS). To prevent the accidental uptake of renin by cells from the culture medium, the M199-PS was never supplemented with serum.

At least $91 \%$ of adherent cells revealed Mo and $97 \%$ of that for AM on the basis of Giemsa staining and non-specific esterase activity (Mueller et al. 1975). Lymphocyte and granulocyte contamination of Mo monolayers was less than $9 \%$. The number of residual platelets that coadhered with monocytes was found to be 10-40/100 monocytes. Alveolar macrophage monolayers showed about $2 \%$ of lymphocytes and few granulocytes and alveolar epithelial cells.

Mo and AM monolayers from each experiment were lyophi- 
lized, washed off the Petri dishes and solubilized with a $0 \cdot 2 \mathrm{M}$ ammonium acetate buffer, $\mathrm{pH} 6.0$, containing $10 \mathrm{~mm}$-EDTA, $0.1 \%$ Triton X-100, phenylmethylsulphonyl fluoride, 8-hydroxyquinoline and dithiothreitol (Sigma Chem. Co., St Louis, MO, USA), each at $2 \times 10^{-3} \mathrm{M}$. After sonication of cells on ice twice, for $25 \mathrm{~s}$ each, the supernatants of a $12000 \mathrm{~g}$ centrifugation were then subjected to a Dowex $50 \mathrm{~W} \cdot \mathrm{X} 2$ cation exchange resin $(100 / 200$ mesh, $0.5 \mathrm{~cm} \times 2 \mathrm{~cm}$, Fluka). Protein fractions eluted with the same buffer, $\mathrm{pH} 6.0$, at $3^{\circ} \mathrm{C}$ (Boucher et al. 1964) were lyophilized and redissolved in HPLC buffer (see below). Portions of the supernatants of sonicated cells, as crude samples without being subjected to a Dowex column, were also freezedried, then redissolved in RIA buffer, i.e. 0.05 $\mathrm{m}$-Tris/albumin, pH 7.4 (Poulsen \& Jörgensen, 1974).

\section{HPLC method}

A Water's HPLC system with a silica-based size exclusion column (Protein-Pak, 300SW, $0.75 \mathrm{~cm} \times 30 \mathrm{~cm}$ ) was used as described (Nielsen \& Poulsen, 1987a). The isocratic elution was maintained at room temperature with a buffer of $0.01 \mathrm{M}$-sodium phosphate $(\mathrm{pH} 7.5)$, containing $0.14 \mathrm{M}-\mathrm{NaCl}$ and $0.3 \mathrm{~mm}$ sodium azide. The flow rate was $0.5 \mathrm{ml} \mathrm{min}^{-1}$ and the proteins in the effluents were monitored continuously at $280 \mathrm{~nm}$ with a Water Lambda-Max spectrophotometer. Fractions were collected every $20 \mathrm{~s}$ into RIA tubes containing $5 \mathrm{mg} \mathrm{m}^{-1}$ human serum albumin (Statens Seruminstitut, Denmark) in a $0.2 \mathrm{M}$ Tris $\cdot \mathrm{HCl}$ buffer, $\mathrm{pH} 7 \cdot 5$, to prevent protein absorption onto the glass wall. The column was standardized earlier with human serum albumin (Behringwerke, Marburg), ovalbumin (Sigma) and cytochrome $c$ from horse heart (Boehringer, Mannheim), as described (Nielsen \& Poulsen, 1987a).

The freeze-dried protein fractions from the Dowex separation were redissolved in 220-350 $\mu$ l of HPLC buffer followed by a $12000 \mathrm{~g}$ centrifugation. The volume injected into the HPLC instrument varied from $150 \mu \mathrm{l}$ to $200 \mu \mathrm{l}$. Each HPLC fraction was freeze-dried then redissolved in $50 \mu \mathrm{l}$ of distilled water, and their renin concentrations were determined by RIA. As a control, $200 \mu$ l of normal mouse plasma was also subjected to the Dowex separation and HPLC procedure as described above and the recovery of renın was determined.

\section{Renin measurement}

The concentration of renin in both crude samples and HPLC fractions was determined by radioimmunoassay based on the antibody trapping method (Poulsen \& Jörgensen, 1974).

During a $4-6 \mathrm{~h}$ reaction time at $37^{\circ} \mathrm{C}$, the angiotensin-I formed and captured by its specific antibody in the presence of high concentration of rat angiotensinogen (Poulsen, 1973), was quantified radioimmunologically (Poulsen \& Jörgensen, 1974). The assay had been standardized earlier with hog renin standard (MRC, Holly Hill, London), so the renin concentration is given in Goldblatt units $(\mathrm{GU}) \mathrm{l}^{-1}$ (Poulsen \& Jörgensen, 1974). To ensure that the generated angiotensin-I (AI) measured by RIA was attributed to renin, the parallel samples were incubated with specific antibody to pure mouse submaxillary gland renin, as well, in order to check the specificity.

\section{Immunohistochemical detection of renin}

Immunoreactive renin in monocytes and alveolar macrophages was detected essentially according to Stenberger (1979). Mo and AM monolayers were prepared in a special detachable sterilizable chamber with a glass bottom (developed at the University Medical School, Debrecen, Hungary). The wells ( $5 \mathrm{~mm}$ in diam.) containing the monolayers were filled with icecold $4 \%$ paraformaldehyde and centrifuged at $600 \mathrm{~g}$ for $15 \mathrm{~min}$ at $3{ }^{\circ} \mathrm{C}$. After removing the fixative, the cells were washed with
$0.05 \mathrm{M}$-Tris-buffered saline, $\mathrm{pH} 7.4$ (TBS), and treated with $0.1 \%$ Triton $\mathrm{X}-100$ for $20 \mathrm{~s}$ then with $0.05 \%$ trypsin solution (Serva), for $4 \mathrm{~min}$ at $3^{\circ} \mathrm{C}$. The monolayers were extensively washed and preincubated for $30 \mathrm{~min}$ in a moist chamber at room temperature with TBS containing $1 \%$ human serum albumin. Alternatively, the Triton-trypsin treatment was omitted and absolute ethanol was used for permeabilization.

For the immunofluorescence staining, the monolayers were incubated for $48 \mathrm{~h}$ in a moist chamber at $3{ }^{\circ} \mathrm{C}$ with anti-renin rabbit IgG (Malling \& Poulsen, 1977) at a dilution of 1:500. The cells were then thoroughly washed with cold TBS for $5 \mathrm{~min}$ (three times) and immersed in absolute ethanol at $-20^{\circ} \mathrm{C}$ before being incubated with the biotinylated anti-rabbit IgG (Amersham, 1:80) for $45 \mathrm{~min}$ at room temperature. After a $10 \mathrm{~min}$ washing, the monolayers were incubated with FITC-labelled streptavidin, diluted 1:50, followed by an extensive washing. The cells were then counterstained with $0.05 \%$ ethidium bromide (Sigma) and mounted in glycerine-TBS. Immunofluorescence staining was viewed in a Leitz Orthoplan microscope equipped with Ploem-type vertical illuminator and selective narrow-band excitation filters for the red (ethidium bromide) and greenish (FITC) fuorochromes.

To test the specificity of the immunofluorescence staining, the following controls were used: (1) AM and Mo monolayers were incubated with FITC-conjugated anti-mouse $\operatorname{IgG}(\mathrm{Fc})$ produced in goat (Nordic, 1:50) in order to check the Fc receptor activity after the fixation procedure described above. (2) The cells were incubated for $48 \mathrm{~h}$ at $3^{\circ} \mathrm{C}$ with anti-renin antibody preabsorbed with an excess of pure submaxillary gland renin (Malling \& Poulsen, 1977) overnight at $3^{\circ} \mathrm{C}$ or with affinity-purified rabbit preimmune IgG in appropriate dilutions, instead of the primary antiserum (negative controls). Additional controls involved omission of one of the components used in the immunocytochemical reaction, i.e. primary antiserum, biotinylated anti-rabbit serum or streptavidin-FITC was omitted.

Antibodies against pure mouse submaxillary gland renin raised in rabbits were purified for renin-specific IgG by affinity chromatography on a renin-Sepharose $4 B$ column. The antibody crossreacts completely with mouse and rat plasma and kidney renin as described in detail (Malling \& Poulsen, 1977; Taugner et al. 1979).

\section{Results}

Normal, unstimulated monocytes from both mice and rats exhibited low, but detectable, amounts of renin that could be almost completely inhibited by specific antibody to pure submaxillary gland renin (Table 1). The enzyme could also be detected after the Dowex procedure, eluted with $0 \cdot 2 \mathrm{M}$-ammonium acetate buffer, $\mathrm{pH} 6 \cdot 0$, and then identified by HPLC, as well. The HPLC elution position of renin in both M-Mo and R-Mo (Fig. 1B,C) was found to be similar to the retention time of active renin from mouse plasma (Fig. 1A). This suggests that monocytederived renin has an apparent molecular weight similar or identical to active plasma renin, i.e. about 25000 (Nielsen \& Poulsen, 1987a). The same observations were obtained with alveolar macrophages from both mice and rats, as judged by the HPLC study. The enzymically active renin in M-AM always eluted as a single peak on HPLC (Fig. 2A,B), whereas the R-AM-derived renin consistently showed a biphasic elution profile (Fig. 2C,D), identified by the angiotensin-I trapping 
Table 1. Renin concentrations in alveolar macrophages and monocytes measured by the angiotensin-I-trapping method

\begin{tabular}{|c|c|c|c|c|c|c|c|c|c|}
\hline \multirow[b]{3}{*}{ Methods } & \multicolumn{4}{|c|}{ Mousc } & \multicolumn{4}{|c|}{ Rat } & \multirow{3}{*}{$\begin{array}{l}\text { \% Recovery } \\
\text { of nornal } \\
\text { mouse plasma } \\
\quad(n=3)\end{array}$} \\
\hline & \multicolumn{2}{|c|}{ Alveolar macrophages } & \multicolumn{2}{|c|}{ Monocytes } & \multicolumn{2}{|c|}{ Alveolar macrophage } & \multicolumn{2}{|c|}{ Monocytes } & \\
\hline & $\begin{array}{l}\text { Renin } \\
\text { concn }\end{array}$ & $\begin{array}{l}\text { \% Renun } \\
\text { inhib. }\end{array}$ & $\begin{array}{l}\text { Renin } \\
\text { concn }\end{array}$ & $\begin{array}{l}\text { कo Renın } \\
\text { inhıb. }\end{array}$ & $\begin{array}{l}\text { Renin } \\
\text { concn }\end{array}$ & $\begin{array}{l}\text { 9o Renin } \\
\text { inhib. }\end{array}$ & $\begin{array}{l}\text { Renin } \\
\text { concn }\end{array}$ & $\begin{array}{l}\text { go Renin } \\
\text { inhib. }\end{array}$ & \\
\hline Crude & $\begin{array}{c}10 \cdot 3 \\
(3 \cdot 20-19 \cdot 7) \\
n=6\end{array}$ & 91.7 & $\begin{array}{c}9 \cdot 08 \\
(3 \cdot 02-19 \cdot 8) \\
n=4\end{array}$ & $88 \cdot 3$ & $\begin{array}{c}8 \cdot 33 \\
(2 \cdot 80-16 \cdot 0) \\
n=6\end{array}$ & $94 \cdot 0$ & $\begin{array}{c}4 \cdot 20 \\
(1 \cdot 80-7 \cdot 80) \\
n=4\end{array}$ & $76 \cdot 1$ & 100 \\
\hline Dowex & $\begin{array}{c}3 \cdot 83 \\
(1 \cdot 24-7 \cdot 10) \\
n=6\end{array}$ & $94 \cdot 0$ & $\begin{array}{c}2 \cdot 74 \\
(1 \cdot 30-6 \cdot 31) \\
n=4\end{array}$ & $79 \cdot 8$ & $\begin{array}{c}3 \cdot 16 \\
(1 \cdot 0-6 \cdot 54) \\
n=6\end{array}$ & $92 \cdot 2$ & $\begin{array}{c}1 \cdot 57 \\
(0 \cdot 72-3 \cdot 2) \\
n=4\end{array}$ & $76 \cdot 8$ & $\begin{array}{c}41 \cdot 6 \\
(36 \cdot 2-51 \cdot 5)\end{array}$ \\
\hline Dowex-HPLC & $\begin{array}{c}3 \cdot 70 \\
(2 \cdot 0-5 \cdot 7) \\
n=3\end{array}$ & $89 \cdot 1$ & $\begin{array}{c}0.99 \\
(0 \cdot 93-1 \cdot 05) \\
n=2\end{array}$ & $90 \cdot 4$ & $\begin{array}{c}4 \cdot 50 \\
(3 \cdot 30-6 \cdot 24) \\
n=3\end{array}$ & $97 \cdot 5$ & $\begin{array}{c}0.61 \\
(0.55-0.67) \\
n=2\end{array}$ & $81 \cdot 2$ & $\begin{array}{c}127 \cdot 3 \\
(90-179)\end{array}$ \\
\hline
\end{tabular}

The methods indicated in the table are described in the text.

- \% Renin inhibition was determined in the presence of anti-renin (1:10 dilution). Values for renin $\left(\times 10^{-6}, \mathrm{GU} / 10^{7}\right.$ cells) are given as the mean with the range in parenthesis.
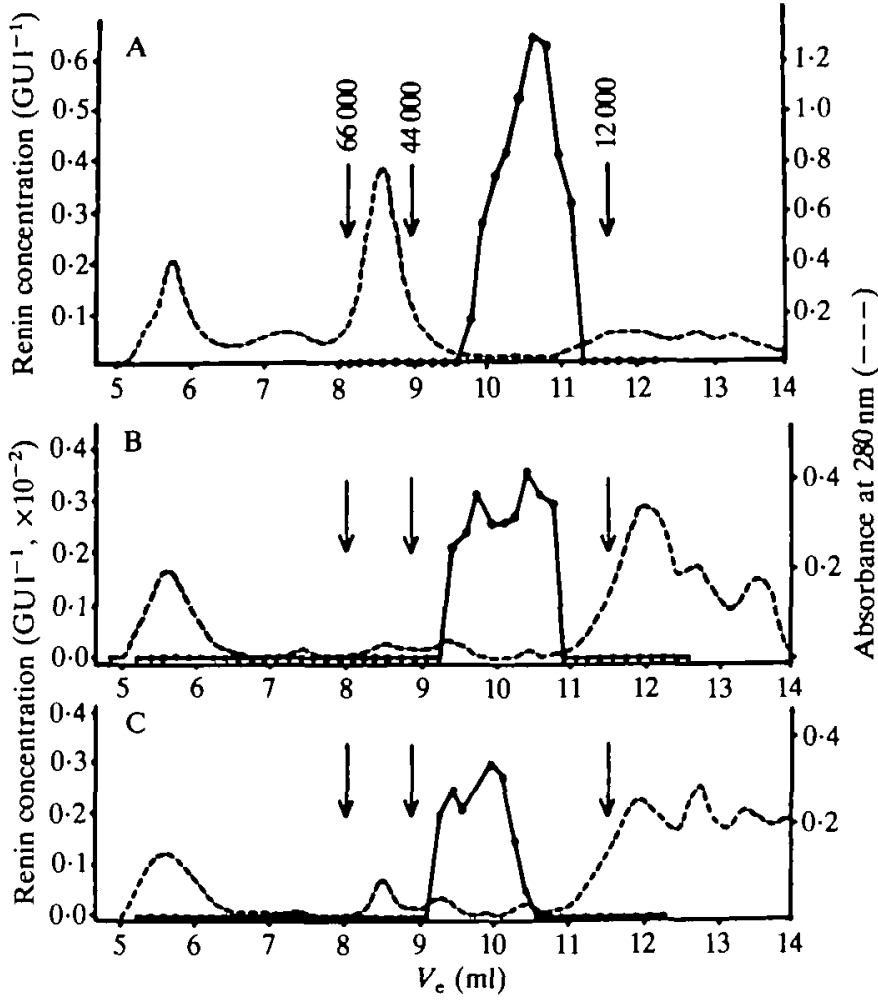

Fig. 1. HPLC profiles for renin of $50 \mu 1$ mouse plasma (A) and $1.2 \times 10^{7}$ to $1.3 \times 10^{7}$ monocytes from mice $(B)$ and rats (C). The sonicated cell supernatants were subjected to Dowex separation and the eluates were injected into the HPLC instrument. The enzymically active renin (O) in the HPLC fractions was measured by the angiotensin-I trapping method. Renin is given in Goldblatt units $(\mathrm{GU}) \mathrm{1}^{-1}$. Protein was monitored by the absorbance at $280 \mathrm{~nm} . V_{\mathrm{e}}=$ elution volume. Positions (shown as $M_{\mathrm{r}}$ ) of human serum albumin $(66000)$, ovalbumin $(44000)$, and cytochrome $c(12000)$ are indicated by arrows. The figure illustrates that the HPLC elution positions of renin in monocytes $(B, C)$ are almost identical to those of active renin from normal mouse plasma, though the monocyte-derived enzyme eluted as a biphasic peak. method. Furthermore, AI generation in AM after a $4-6 \mathrm{~h}$ incubation at $37^{\circ} \mathrm{C}$ in the presence of a high concentration of angiotensinogen could also be inhibited, with anti-renin (Table 1, even columns). This indicates that AI production is not due to the non-specific action of substances other than renin in these cells during the enzymic reaction.

Renin could not be detected in samples without cells. The mean values of the renin concentration in alveolar macrophages and monocytes are summarized in Table 1. The recovery of renin in AM and Mo after the Dowex procedure varied from $31 \%$ to $43 \%$ as compared to the renin contents that could be detected in crude samples, measured by RIA. In contrast to this, no appreciable loss of renin was observed when the Dowex eluates $(100 \%)$ were subjected to HPLC. These data agree with the results of a recovery study of normal mouse plasma (Table 1)

Finally, an immunocytochemical study was also performed in order to identify the cells that share the enzyme renin that was observed biochemically in AM and Mo preparations.

The distribution of renin in alveolar macrophage and monocyte monolayers is illustrated in Fig. 3. On the basis of the nuclear morphology, alveolar macrophages (Fig. 3A,B) and monocytes (Fig. 3C,D) expressed immunoreactive renin, which completely disappeared when the cells were incubated with either anti-renin preabsorbed with pure renin or affinity-purified preimmune rabbit $\operatorname{IgG}$ in place of the anti-renin antibody (Fig. 3A-D). Thus, this serves as morphological evidence that these cell types were responsible for the observed renin identified using the biochemical methods described above.

However, it is noteworthy that renin positive cells were fairly low in number as compared to the total adhered particles on monolayers: only $25-29 \%$ of the alveolar macrophages and $33-36 \%$ of the monocytes $(n=6-6)$ could be stained with the fluorochrome, although their 

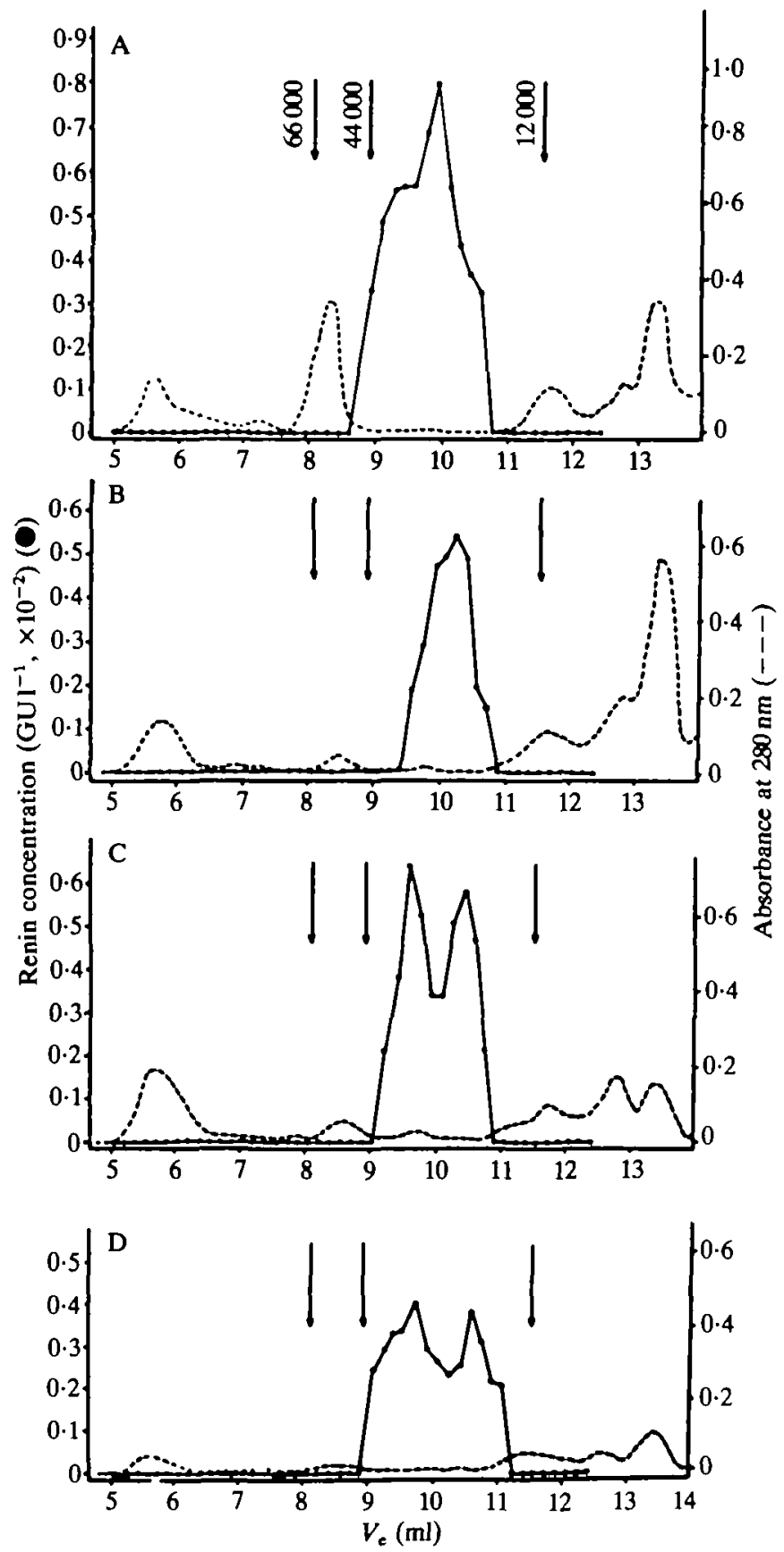

Fig. 2. HPLC profiles for renin (O) of: $A, B, 0.7 \times 10^{7}$ to $0.8 \times 10^{7}$ mouse alveolar macrophages (M-AM); and C,D, $0.3 \times 10^{7}$ to $0.6 \times 10^{7}$ rat alveolar macrophages (R-AM) from separate experiments. (The methods are indicated in Fig. 1.) Renin in AM has a similar elution position to that of plasma renin (Fig. 1). In contrast to M-AM, the enzymically active renin from R-AM eluted as a biphasic curve.

prominent cytoplasmic staining was conspicuous using Triton-trypsin pretreatment (Fig. 3A,C).

In contrast, pale and scattered fine granular positivity was observed in some alveolar macrophages after treatment with ethanol was used in place of trypsin and detergent (Fig. 3B). As the photomicrograph for monocytes illustrates, no appreciable fluorescence could be observed in lymphocytes (Fig. 3B,C, arrows). Thus, it is apparent that these cells do not contain morphologically detectable renin.

On the basis of the observations with FITC-labelled anti-mouse $\operatorname{IgG}(\mathrm{Fc})$, neither $A M$ nor Mo expresses $F_{c}$ receptor activity under the fixation procedures used. It seems reasonable to assume that the anti-renin antibody bound to cells did not interfere with the $\mathrm{Fc}$ receptors.

\section{Discussion}

Renin has recently been demonstrated in 3T3 and neuroblastoma cell lines (Fishman et al. 1981; Okamura et al. 1981; Schelling et al. 1979), in different normal tissues of extrarenal origin (Naruse et al. 1985), in thioglycollate-provoked inflammatory granulocytes (Nielsen \& Poulsen, 1987b) and in macrophages isolated from shistosoma-induced granulomas (Weinstock \& Blum, 1983). This angiotensin-I-generating protease has now been identified in normal, unstimulated alveolar macrophages and monocytes from both mice and rats. The above data expand our earlier observations that these resting cells contain not only angiotensins, but renin as well.

On the basis of the present study, the AI-generating enzyme purified partially on HPLC, has a similar or identical molecular weight to plasma renin and is almost completely inhibited by anti-renin IgG, indicating that the protease, detected in AM and Mo is identical to true renin. These results are in agreement with the observations made in the cytochemical study, since the cells that shared immunoreactive renin are macrophages and monocytes. The low percentage of renin-positive cells might indicate a functionally different and probably distinct subpopulation of AM and Mo. If this is the case, the enzyme renin could be an immunohistochemical marker for a certain subpopulation of AM as well as for Mo.

The presence of renin and angiotensins (Dezsö et al. 1988) in alveolar macrophages and monocytes seems to be a common, not an isolated extraordinary, event. The data obtained here are in accordance with the observation of Fernandez et al. (1986), who found renin positive cells in a series of lymph nodes with angiolymphoid hyperplasia with eosinophilia; however, the origin of these particles could not be unambiguously identified. These data seem to support Goldblatt's hypothesis that there may be a

Fig. 3. Immunoreactive renin in alveolar macrophages from mice $(A)$, rats $(B)$, and monocytes from mice $(C)$ and rats (D). The monolayers fixed with paraformaldehyde were treated with Triton X-100 and trypsin (A,D) or with absolute ethanol $(B, C)$. A double immunofluorescence technique was performed by incubating the cells with rabbit anti-renin IgG for $48 \mathrm{~h}$ at $3^{\circ} \mathrm{C}$. The specific binding was visualized by using biotinylated anti-rabbit IgG and streptavidin-FITC. The cel nuclei were then counterstained with ethidium bromide. The renin positive cells show conspicuous cytoplasmic fluorescence. Arrows indicate lymphocytes that lack staining for renin. Controls for specificity $\left(A^{\prime}, B^{\prime}, C^{\prime}, D^{\prime}\right)$ showing absence of FITC staining when the cells are incubated with rabbit preimmune $\lg G$ in place of the primary antibody. Scale Bar, $50 \mu \mathrm{m}$. 

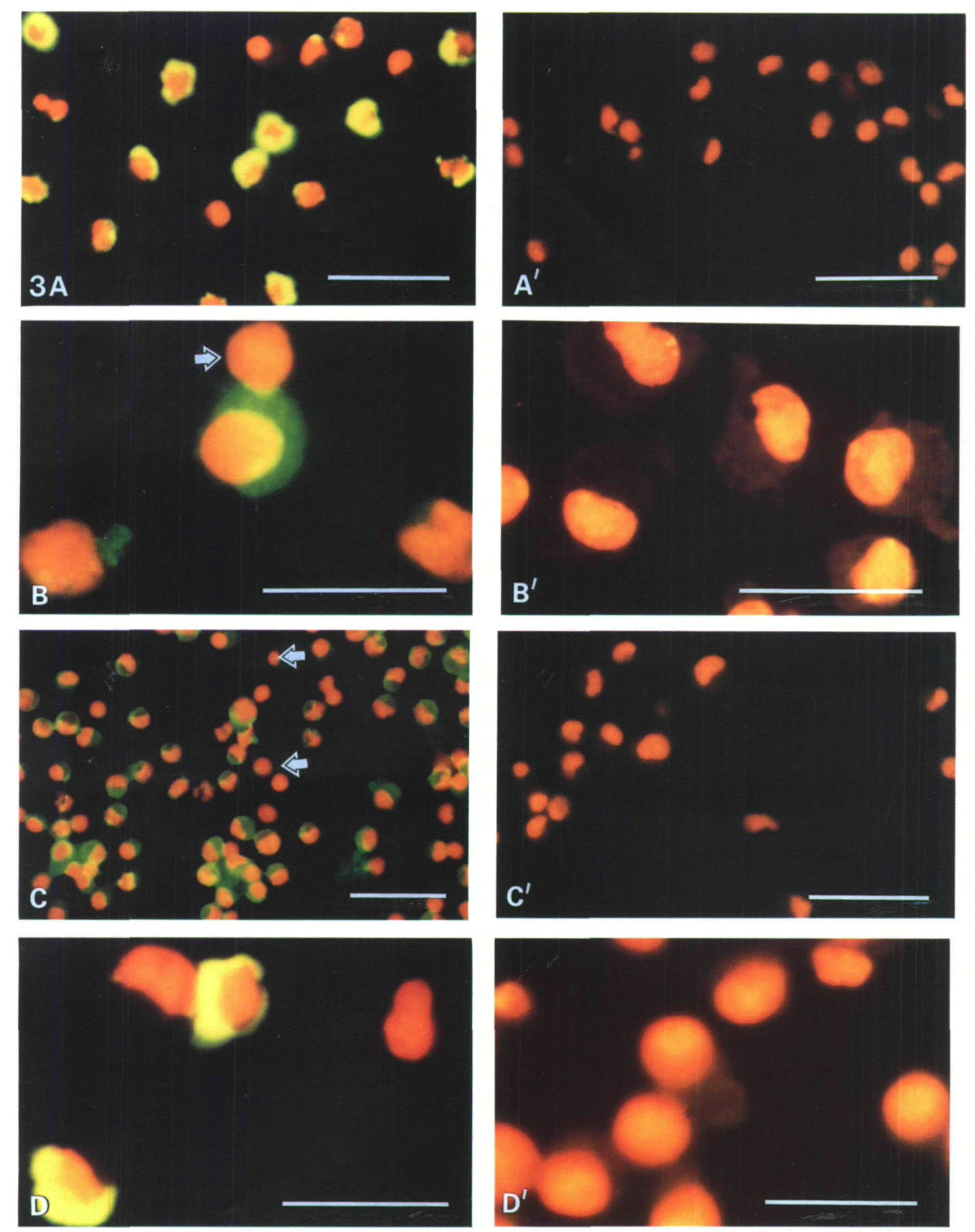

population of cells distributed throughout the body with the ability to synthesize or take up renin, which may serve as a local intracellular or extracellular regulator (Goldblatt, 1986).

Although, the origin of renin in AM and Mo has not been elucidated, the fact we could isolate and measure enzymically active renin from cells strongly suggests intracellular formation not endocytosis by these mononuclear phagocytes. Our preliminary findings, described above, together with earlier data for the presence of angiotensins (Dezsö et al. 1988) and angiotensin-Iconverting enzyme (Grönhagen-Riska et al. 1986; Rohrbach, 1984; Silverstein et al. 1979) raise the interesting possibility that an intracellular renin-angiotensin system may exist in a certain subpopulation of normal macrophages and monocytes. Clearly these points merit further investigation.

The technical assistance of Marianne Dunk is acknowledged. This work was supported by the Danish Medical Research Council with the help of which the first author worked for 6 months at the Department of Biochemistry, Royal Dental College, Copenhagen, in 1986.

\section{References}

Alblas, A. B. \& FURTH, R. vaN (1979). Origin, kinetics, and characteristics of pulmonary macrophages in the normal steady state. F. exp. Med. 149, 1504-1518.

Boucher, R., Veyrat, R., Champlain, J. \& Genest, J. (1964). New procedures for measurement of human plasma angiotensin and renin activity levels. Can. med. Ass. J. 25, 194-201.

Boyum, A. J. (1968). Separation of leukocytes from blood and bone marrow. Cin. Lab. Invest. 21 (Suppl. 97), 77-109.

Dezso, B., Jacobsen, J., Nielsen, A. \& Poulsen, K. (1988). Evidence for the presence of angiotensins in normal, unstimulated alveolar macrophages and monocytes. F. Hypertension (in press).

Fernandez, L. A., Olsen, T. G., Barwick, K. W., Sanders, M., KaliszewsKi, C. \& INAGAMI, T. (1986). Renin in angiolymphoid hyperplasıa with eosinophilia. Archs Path. Lab. Med. 110. 1131-1135.

Fishman, M. C., Zimmerman, E. A. \& Slater, E. E. (1981). Renin and angiotensin: the complete system within the neuroblastoma $\times$ glioma cell. Science $214,921-923$.

Ganten, D., Hutchinson, J. S., Schelling, P., Ganten, U. \& FISHER, H. (1976). The iso-renin angiotensin systems in extrarenal tissuc. Clin. expl Phannac. Physiol. 3, 103-126.

Goldblatt, P. J. (1986). What is the role of external Renin? Archs Path. Lab. Med. 110, 1128-1130.

Gronhagen-Riska, C., Fyhrquist, R. \& Willebrand, E. von (1986). Angiotensin I-converting enzyme. A marker of highly differentiated monocytic cells. Ann. N.Y. Acad. Sci. 465, 242-249.

Klickstein, L. B., Kaempfer, C. E. \& Wintroub, B. U. (1982).

The granulocyte-angiotensin system. 7. biol. Chem. 257, $15042-15046$.

Malling, C. \& Poulsen, K. (1977). A direct radioimmunoassay for plasma renin in mice and its evaluation. Biochmn. biophys. Acta 491, 532-541.

Mueller, J., Brun del Re, G., Buerki, H., Keller, H. U., Hess, M. W. \& Cottier, H. (1975). Nonspecific acid esterase activity, a criterion for differentiation of $\mathrm{T}$ and $\mathrm{B}$ lymphocytes in mouse lymph nodes. Eur. 7. Immun. 5, 270-274.

Naruse, K., Murakoshi, M., Osamura, R. Y., Naruse, M., Toma, H., Watanabe, K., Demura, H., Inagami, T. \& SHIZUME, K. (1985). Immunohistological evidence for renin in human endocrine tissues. J. clin. Endocr. Metab. 61, 172-177.

NiElsen, A. H. \& Poulsen, K. (1987a). Quantitative activations and determination of inactive renin by using HPLC. $\mathcal{F}$. Hypertension 5, 25-29.

Nielsen, A. H. \& Poulsen, K. (1987b). Absence of processing enzymes for inactive renin in mouse blood but polymorphonuclear neutrophils contain active renin. J. Hypertension 5, 469-474.

Okamura, T., Clemens, D. L. \& Inagami, T. (1981). Renin, angiotensins and angiotensin-converting enzyme in neuroblastoma cells: cvidence for intracellular formation of angiotensins. Proc. natn. Acad. Sci. U.S.A. 78, 6940-6943.

POULSEN, K. (1973). Kinetics of the renin system. Scand. J. clin. Lab. Invest. 31 (Suppl. 132), 1-86.

Poulsen, K. \& JORGENSEN, J. (1974). An easy radioimmunological microassay of renin activity, concentration and substrate in human and animal plasma and tissue based on angiotensin I trapping by antibody. F. clin. Endocr. Metab. 39, 816-825.

Rohrbach, M. S. (1984). Metabolism and subcellular localization of angiotensin converting enzyme in cultured human monocytes. Biochem. biophys. Res. Commun. 124, 843-849.

Schelling, P., Ganten, D., Speck, G. \& Fisher, H. (1979). Effects of angotensin II and angiotensin antagonist saralasin on cell growth and renin in 3T3 and SV3T3 cells. 7. cell. Physiol. 98, 503-514.

Silverstein, E., Pertschuk, L. P. \& Friedland, J. (1979). Immunofluorescent localization of angiotensin converting enzyme in epithelıoid and giant cells of sarcoid granulomas. Proc. natn. Acad. Sci. U.S.A. 76, 6646-6648.

STENBERGER, L. A. (1979). Immunofluorescence. In Immunocytochemistry, Pp. 24-59. New York: John Wiley and Sons.

Taugner, Ch., Poulsen, K., Hackental, E. \& Taugner, R. (1979). Immunocytochemical localization of renin in mouse kidney. Histochemistry 62, 19-27.

Tonnesen, M. G., Klempner, M. S., Austen, K. F. \& Wintroub, B. U. (1982). Identification of a human neutrophıl angiotensin IIgenerating protease as cathepsin G. F. clin. Invest. 69, 25-30.

Weinstock, J. V. \& Blum, A. M. (1983). Isolated liver granulonas of murine schistosoma mansoni contain components of the ang1otensin system. J. Immun. 131, 2529-2532.

(Recetved 25 January 1988 - Accepted, in revised form, 8 June 1988) 
